\title{
FERMENTABLE SUGARS FROM Lupinus rotundiflorus BIOMASS BY CONCENTRATED HYDROCHLORIC ACID HYDROLYSIS
}

\author{
J. Jesús Vargas Radillo, a Mario A. Ruiz-López, 'Ramón Rodríguez Macías, ${ }^{b}$ \\ Lucía Barrientos Ramírez, , Pedro M. García-López, \\ and Fernando A. López-Dellamary Toral ${ }^{\mathrm{a}^{*}}$
}

\begin{abstract}
It is of general interest to produce fermentable carbohydrates from plant biomass. However, obtaining monosaccharides requires some effort, due to the intricate structure of the cell wall lignocellulosic complex. The aim of this study was to apply a simple two-stage hydrolysis process, using only concentrated hydrochloric acid, to generate fermentable carbohydrates from $L$. rotundiflorus biomass. First and second stage acid concentrations were $32 \%$ and $42.6 \%$. Total monosaccharide yields with respect to dry matter after the first stage, second stage, and the overall process, were $27.5 \%, 21.0 \%$ and $48.4 \%$, respectively. Xylose was the main first stage carbohydrate in the hydrolysate, followed by glucose, arabinose, and galactose. After the second stage only glucose and a small amount of xylose were detected. The polysaccharide hydrolysis was eased by overall low lignin content. Some advantages of this method were the use of a single hydrolyzing agent and that most of the polysaccharides were hydrolyzed in reasonably high yields. The acceptable yield, relative simplicity, the use of most of the biomass along with the wide availability, low cost of the chemicals, and the ample supply of lupines, would facilitate the scaling of these laboratory studies to pilot and industrial levels.
\end{abstract}

Keywords: Lupinus; Carbohydrate; Hydrolysis; Morphology; Holocellulose; Fermentable

Contact information: a: Departamento de Madera, Celulosa y Papel, Universidad de Guadalajara, Km 15.5, Carretera Guadalajara-Nogales, Las Agujas, Nextipac, Zapopan, Jalisco, México, código postal 45220; b: Centro Universitario de Ciencias Biológicas y Agropecuarias, Universidad de Guadalajara, Km 15.5, Carretera Guadalajara-Nogales, Las Agujas, Nextipac, Zapopan, Jalisco, México, código postal 45220; *Corresponding author: fernando.dellamary@cucei.udg.mx

\section{INTRODUCTION}

Lignocellulosic biomass is an abundant, inexpensive and renewable resource, which can be utilized for the production of alcohols at a reasonable cost. Conversion of this biomass into alcohols is a difficult process due in part to the complexity of the plant's fiber cell wall. The cell wall is composed of cellulose (38-50\%), hemicelluloses (1732\%), lignin (15-30\%) as well as proteins, pectins, and extractives (Kamm et al. 2006; Moxley and Zhang 2007; Silverstein et al. 2007; Ritter 2008). Hydrolysis of lignocellulosic materials, especially the enzymatic hydrolysis, is affected by substrate characteristics such as mechanical properties, morphology, crystallinity, and chemical structure (Lee et al. 1982). Morphological analysis of the plant material may be of 
practical use in helping to predict the accessibility to hydrolysis of the polysaccharides comprising the plant tissues, particularly that of fibers and parenchyma from which fermentable carbohydrates could be released. Thus, anatomical structural analysis of the material is of help in qualitatively predicting how easily the acid will penetrate these structures, by observing if the fibers are closely bound to each other, by the distribution of the fibers, by the ratio and distribution of parenchyma in relation to fibers, etc. It is assumed that parenchyma will be easier to hydrolyze, since it is made up of amorphous non-fibrous cellulose and hemicelluloses with little or no lignin, in contrast to fibers wherein cellulose is present within a lignocellulosic complex, in which lignin is very refractive to hydrolysis. Also, the cellulosic fibers have a clearly higher degree of crystallinity (Fengel and Wegener 1989), making them somewhat impervious to acid penetration. Both parenchyma and fibers have similar monosaccharide composition, as has been reported elsewhere (Jones et al. 1979).

For the reasons just described, pretreatment and hydrolysis of this raw material for subsequent fermentation by yeast are the main hurdles in the production of alcohols from lignocellulosic feedstocks (Sánchez and Cardona 2005). Pretreatment alters the lignocellulosic matrix, thus allowing the subsequent hydrolytic degradation of polysaccharides to monosaccharides (saccharification). These processes may be carried out by either biotechnological methods preceded by physical or physicochemical treatments, or by chemical methods with dilute acids at high temperature (Iranmahboob et al. 2002), concentrated acids at low temperatures (Pessoa et al. 1997), or a combination of both (Kamm et al. 2006). Mineral acid hydrolysis has been described at least since 1819 (Harris and Beglinger 1946). Acid hydrolysis may be divided into two general approaches (Bergius 1937; Ladisch 1979; Taherzazeh and Karimi 2007; Galbe and Zacchi 2002): A) Concentrated acid at low temperatures, and B) dilute acids at high temperatures, which can be performed with different acids, such as sulphurous, sulphuric, hydrochloric (Israilides et al. 1978; Goldstein et al. 1983), hydrofluoric, phosphoric (Israilides et al. 1978), nitric and formic, using low solids loadings $(5-10 \% \mathrm{w} / \mathrm{w})$ (Brennan et al. 1986; Converse et al. 1989) or high solids loadings $(10-40 \% \mathrm{w} / \mathrm{w})$ (Esteghlalian et al. 1997). There are several concentrated $\mathrm{HCl}$ processes. The earliest one was used in Germany from 1935 to 1948, where full scale plants were built; it is known as the Bergius-Rheinau process. This process uses one $41 \% \mathrm{HCl}$ hydrolysis stage with a 3:1 acid:wood ratio. The modified Bergius process known as Udic-Rheinau, consists of three stages; a pre-hydrolysis with $35 \% \mathrm{HCl}$ at $20^{\circ} \mathrm{C}$, a main hydrolysis with $41 \% \mathrm{HCl}$, and a post-hydrolysis with dilute acid. Most of the acid is recovered by azeotropic distillation at $36^{\circ} \mathrm{C}$, and the residual acid is removed from the syrup by drying it in a hot air spray diffuser (Fengel 1984; Ladisch 1979). Nevertheless, an improved and efficient $\mathrm{HCl}$ recycling process is necessary to make the Bergius process competitive. Attaining this goal has stimulated a lot of research. Recently the Israeli company $\mathrm{HCl}$ CleanTech, has developed a proprietary $\mathrm{HCl}$ recovery process, recovering $\mathrm{HCl}$ in gaseous form directly from aqueous solutions by using an immiscible extractant, such as trilaurylamine-dinonylnaphtalene sulfonic acid in a hydrocarbons diluent having a boiling range starting at $210^{\circ} \mathrm{C}$ (Eyal and Baniel 2010), which makes the modified BergiusRheinau process economically attractive and "clean". A pilot plant running this process was built at Southern Research Institute, North Carolina, U.S. and is working since June 
2010. The plant takes in 1.25 tons per day of cellulosic feedstock. It is claimed that the cost of the sugars produced is at least $17 \%$ lower than the cost of corn mill sugars and of similar quality (HCl Clean Tech 2010).

On the other hand the Fabaceae (Leguminosae) is a plant family amply distributed around the world and economically very important as a food source. The Lupinus genus belongs to this family and consists of around 300 species, with some 2000 synonymia (Gladstones 1998); it is widely distributed in the Americas and Mediterranean regions with ca. 80 native species described for Mexico (McVaugh 1987; Rzedowski and Rzedowski 2001). L. rotundiflorus is a wild lupine (sometimes spelled "lupin") that grows in Mexico at altitudes of 1500 to $2000 \mathrm{~m}$ above sea level in the Pacific mountains and the western part of the volcanic axis, in pine and oak forest clearings, and near roadsides. It is an herbaceous plant; its branched basal crown consists of a small stem that underlines a cluster of many shoots. It is an available and fairly common wild species, easy to collect and with a potential to be established as a commercial crop (Ruiz et al. 2000). Elsewhere other lupines have been investigated and developed to be used as commercial crops. Thus, for example, Alaska-lupine today is grown in Iceland, where it was introduced in 1945, with yields (dry mass) ca. 7-8 ton/ha/year (Kamm 2006). Some of this production using the modified "Bergius/Rheinau" process is aimed at the biofuels and biorefinery (ethanol and lignin) markets. Also lupines are grown and processed extensively in Australia, Andean countries, and some European countries (Bañuelos et al. 2006). Although wild lupine species are widely distributed in Mexico, their utilization as animal feed or for human consumption is limited by their high alkaloid content without further processing. Production of fermentable sugars from this biomass can be an alternative use for this Mexican wild species. Therefore, the objective of this study was to evaluate the yield of fermentable soluble carbohydrates from Lupinus rotundiflorus biomass, choosing a proven and industrially successful 2-stage concentrated hydrochloric acid process, followed by a post-hydrolysis with diluted acid. This method is based on the modified Bergius process (Kamm 2006).

\section{EXPERIMENTAL}

The whole experimental procedure is schematized as shown in Fig. 1.

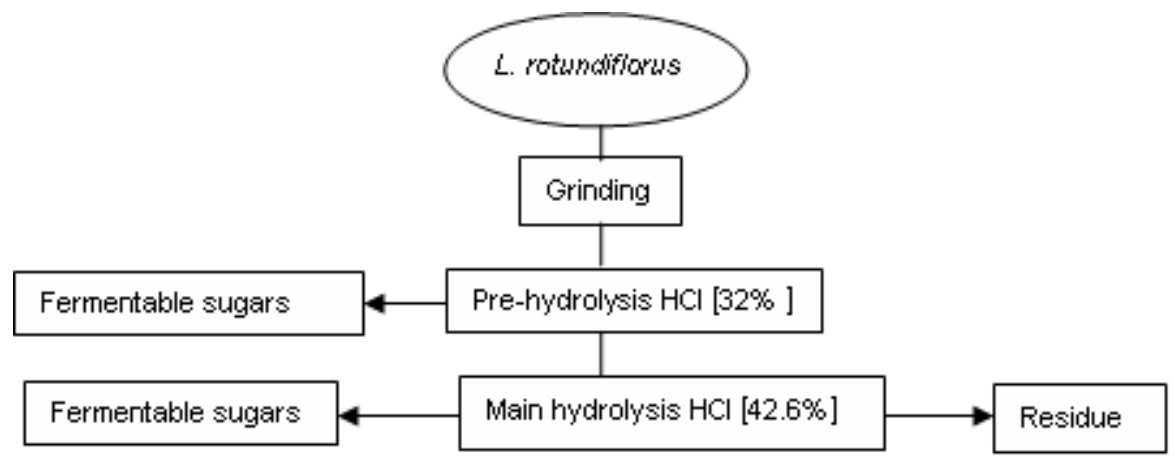

Fig. 1. Schematic presentation of the acid saccharification of $L$. rotundiflorus

Vargas Radillo et al. (2011). "Sugars from lupine biomass," BioResources 6(1), 344-355. 346 


\section{Plant Collection and Sample Preparation}

Whole plants of $L$. rotundiflorus were collected in the wild form during their flowering stage in October, 2008, at $2320 \mathrm{~m}$ above sea level in the vicinity of Atemajac de Brizuela, a town situated in western Mexico, $105 \mathrm{Km}$ SW of Guadalajara, Jalisco. They were air dried and separated into stems, branches, roots, and leaves. Each part was then ground in a Wiley mill with $0.5 \mathrm{~mm}$ screen and stored in plastic bags at $-4^{\circ} \mathrm{C}$. Holocellulose (hemicelluloses and cellulose) (Wise et al. 1946), acid insoluble lignin (TAPPI T222), and extractives (TAPPI T264) content of each part were determined as described in the literature. Particularly, in the Wise procedure for the determination of holocellulose, each extractive-free ground sample is treated with one percent $(1 \%$; w/v) sodium chlorite followed by glacial acetic acid in a water bath at $70^{\circ} \mathrm{C}$. The reaction is allowed to continue for $4 \mathrm{~h}$, adding each hour acetic acid and sodium chlorite. The sample is filtered through a medium porosity filter glass previously weighed and is dried in a vacuum oven at $40^{\circ} \mathrm{C}$ until constant weight.

These analyses were carried out to evaluate which plant parts had a higher content of hydrolysable carbohydrates, hence making it possible to decide which parts would be desirable to process and which to discard. Thus the foliage was cast aside.

\section{Anatomy}

Transversal histological sections, $20 \mu \mathrm{m}$ thick, were prepared from the basal stem using a Leica Microtome. Some of the sections were stained with safranine and astral blue. Both stained and non-stained sections were placed on microscope slides and fixed in euparal mounting medium (Burger and Richter 1991).

The maceration study was carried out according to Franklin (1937). Sections of external cortex, internal cortex, and xylem were placed in test tubes, then a mixture of glacial acetic acid and 30\% hydrogen peroxide at a 1:2 (v/v) ratio was added and heated to $60^{\circ} \mathrm{C}$ until the tissue was soft. The softened tissues were removed, drained, and then stained and fixed in the same manner as the transversal sections. The histological observations were done using a Wild compound light microscope at $10 \mathrm{X}$ and $40 \mathrm{X}$ magnification. The length and diameter of 30 fibers were measured using a certified scale attached to the microscope ocular.

\section{Acid Hydrolysis}

All chemicals used were of reagent grade and the water was deionized. $20 \mathrm{~g}$ of ground plant material (o.d. basis) were hydrolyzed with $100 \mathrm{~mL}$ of $32 \%(\mathrm{w} / \mathrm{w}$ ) hydrochloric acid in a $250 \mathrm{~mL}$ Erlenmeyer flask sealed with a rubber stopper for $24 \mathrm{~h}$ in an orbital shaker at $20^{\circ} \mathrm{C}$. After this, the suspension was diluted tenfold with water, heated for $30 \mathrm{~min}$ at $100^{\circ} \mathrm{C}$, filtered, and then washed twice with $50 \mathrm{~mL}$ of water. The combined filtrate and washings were concentrated to around $15 \mathrm{~mL}$ using a rotary evaporator $\left(\mathrm{T}=40^{\circ} \mathrm{C}, \mathrm{p}=200\right.$ mbar) until a thick syrup was formed, this evaporation eliminated most of the acid. The syrup was taken to near neutrality by removing the residual $\mathrm{HCl}$ by addition of ethanol $(4 \times 100 \mathrm{~mL})$ with subsequent distillation to dryness, after which the residue was fully dried in an exsiccator. The solid residue from the first hydrolysis was digested likewise for $24 \mathrm{~h}$ at $20^{\circ} \mathrm{C}$, using $100 \mathrm{~mL}$ of $42.6 \%(\mathrm{w} / \mathrm{w})$ hydrochloric acid (produced by bubbling pure gaseous $\mathrm{HCl}$ into concentrated reagent 
grade $\mathrm{HCl}$ ) (Kirk 1984), filtered, and rinsed twice with $50 \mathrm{~mL}$ of water. The liquid portion was concentrated and dried as described above (Kamm et al. 2006). Sugars recovered from the liquid fractions of the first and second hydrolysis were weighed. The solid residues remaining in both stages of hydrolysis were dried at $40^{\circ} \mathrm{C}$ for $48 \mathrm{~h}$, weighed, and analyzed to quantify lignin and holocellulose content. This procedure was carried out in duplicate.

The yield of fermentable sugars was evaluated by the difference in holocellulose content on each hydrolytic stage, and verified directly by the weight of the thick syrup (concentrated sugars), as a simple alternative to the DNS method (Miller 1959) commonly used in the evaluation of total reducing sugars.

\section{Sugar Analysis}

Monosaccharides were determined using a Varian HPLC (Vista 5500) equipped with a refractive index detector (Varian model 350), a polymeric Hamilton HC-75 Ca (305 x $7.8 \mathrm{~mm})$ column at $80^{\circ} \mathrm{C}$, and HPLC-grade water as the mobile phase $(0.6$ $\mathrm{mL} / \mathrm{min})$. Sugars were quantified using D-glucose, D-xylose, D-galactose, D-arabinose, and D-mannose as external standards. Chromatograms were processed using the Star Varian software.

Solid samples from untreated raw material were totally hydrolyzed with sulfuric acid (72\% w/w), then neutralized with barium hydroxide (ASTM Method 1758-01), filtered through a $0.45 \mu \mathrm{m}$ Millipore nylon membrane, and passed through cationic, anionic, and $\mathrm{C}_{18}$ cartridges. In order to assay the relative amounts of different monosaccharides in the hydrolizates (liquid filtrates), one milliliter of the concentrated (after rotary evaporation) first and second acid filtrates, was diluted to $1 \mathrm{~L}$ in water and then an aliquot filtered and passed through cartridges and HPLC analyzed as has been described above for the solid samples.

Sugars conversion as percentage of the theoretical glucose yield obtained from the equation for the hydrolysis process of cellulose to sugar

$$
\left(\mathrm{C}_{6} \mathrm{H}_{10} 0_{5}\right)_{\mathrm{n}}+\mathrm{H}_{2} \mathrm{O} \longrightarrow\left(\mathrm{C}_{6} \mathrm{H}_{12} \mathrm{O}_{6}\right)_{\mathrm{n}}
$$

was calculated as follows (Mandels et al. 1976),

$$
\text { glucan conversion efficiency }=\frac{\text { weight of glu cose formed } x(162 / 180)}{d r y \text { weight of cellulose used }} \times 100
$$

where a factor of $162 / 180$ was applied due to the difference in mass between the anhydroglucose ring and glucose. Similarly, a factor of 132/150 was applied due to the mass change in the hydrolysis of xylans to xylose.

The fermentable sugars yield was also calculated with respect to the input dry raw material, and as grams per $100 \mathrm{~g}$ raw material. This helps to give an idea about of the amount of fermentable sugars that could be obtained from the material (Sassner et al. 2008). 


\section{RESULTS AND DISCUSSION}

\section{Anatomic Characteristics}

All weight and percent compositions are given on an oven-dry basis. The plant percent weight composition was $12 \%$ roots, $57 \%$ stem and branches, $29 \%$ leaves, and $2 \%$ flowers and pods. Upon microscopic examination (Fig. 2) of a basal stem transversal section, the external cortex, internal cortex, and xylem of L. rotundiflorus contained fibers, some were gelatinous, with a density of 90 fiber $/ \mathrm{mm}^{2}$, xylem having the highest density. Fibers showed little lignification, with thick cell walls and sharp angular ends. The fiber's average length, diameter, and cell wall thickness were $1.1 \mathrm{~mm}, 19 \mu \mathrm{m}$, and $4.9 \mu \mathrm{m}$, respectively. The xylem's fibers were shorter than those of the external and internal cortex. L. rotundiflorus fibers were longer than those reported for $L$. meridanus or L. eromonomos $(0.5 \mathrm{~mm}$ for the stem fibers and $0.78 \mathrm{~mm}$ for the root fibers) collected respectively in Venezuela at 3000 and $4200 \mathrm{~m}$ above sea level (Briceño 2000).
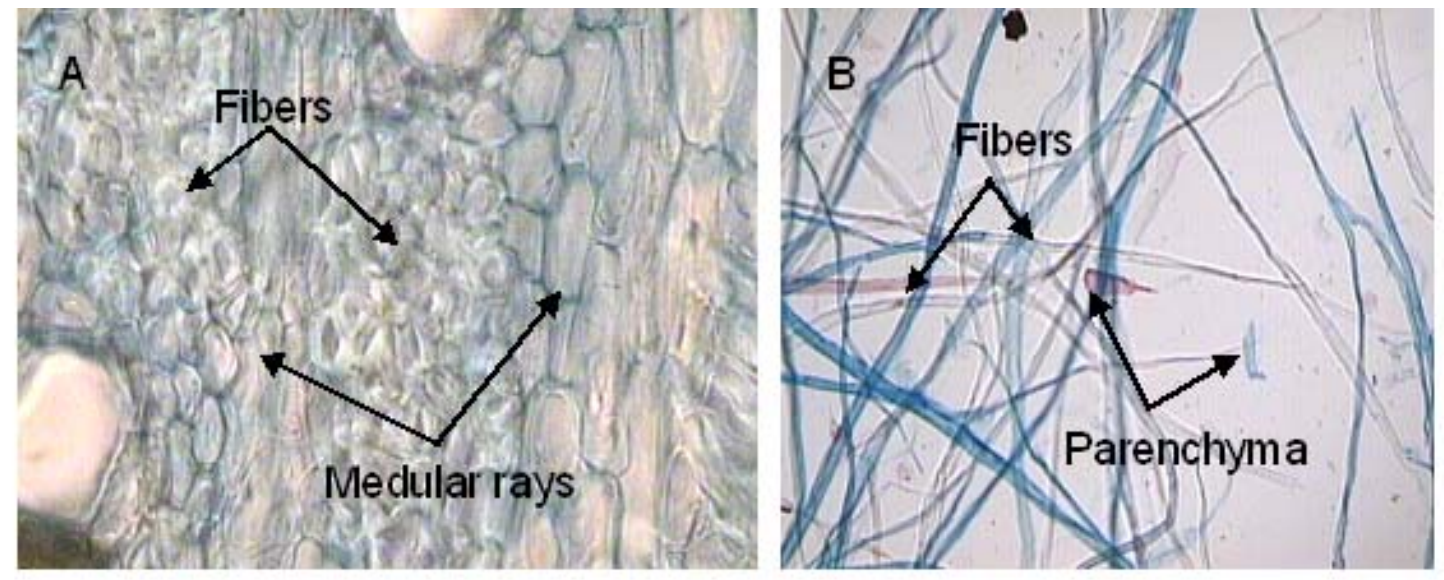

Fig. 2. Optical microscope micrographs of $L$. rotundiflorus:

A. Basal stem transversal section, 40X. B. Macerated material, 10X

\section{Chemical Composition}

The holocellulose content (Table 1) found in the stem, root, and branches was within the normal range (53-82\%), although lignin content was lower than the 15 to 30\% reported in common plant material (Ritter 2008). This difference could be due to the phenological stage of the plant at the time of collection. Leaves (petioles included) contained the lowest levels of holocellulose and lignin. Nevertheless, their lignin content $(10.3 \%)$ was similar to those reported for the leaves of some leguminous plants such as soybean (10.7\%) (Johnson et al. 2007).

Table 1 indicates the monosaccharide content of the four plant parts analyzed. In general, glucose was found in the highest relative concentration followed by xylose, galactose, arabinose, and mannose in that order. In contrast, leaves contained relatively higher concentrations of arabinose, galactose, and mannose in comparison with the other plant parts. The arabinose and mannose content was less than $7 \%$, with roots having the lowest levels $(0.4 \%$ and $0.5 \%)$. 
Table 1. Chemical Composition and Monosaccharide Content of $L$. rotundiflorus Plant Parts (\%)

\begin{tabular}{|c|c|c|c|c|c|c|c|c|}
\hline Plant Part & Holocellulose & Lignin & Extractives & $\mathrm{Ara}^{1}$ & $\mathrm{Gal}^{1}$ & $\mathrm{Glu}^{1}$ & $\mathrm{Xyl}^{1}$ & $\mathrm{Man}^{1}$ \\
\hline Stem & 72.2 & 14.0 & 15.4 & 4.0 & 13.0 & 61.2 & 20.7 & 1.1 \\
\hline Branches & 65.6 & 13.2 & 25.6 & 3.2 & 12.3 & 63.8 & 19.6 & 1.1 \\
\hline Roots & 69.7 & 11.7 & 19.4 & 0.4 & 12.5 & 61.4 & 25.2 & 0.5 \\
\hline Leaves & 47.0 & 10.3 & 37.4 & 6.2 & 16.0 & 61.4 & 11.2 & 5.2 \\
\hline
\end{tabular}

Ara=Arabinose; Gal=Galactose; Glu=Glucose; Xyl=Xylose; Man= Mannose

${ }^{1}$ Relative percent composition

Plant without foliage (Table 2), which was used for acid hydrolysis, contained $62.6 \%$ holocellulose, $15.8 \%$ lignin, and $22.6 \%$ extractives; while monosaccharide content was similar to that found in each plant part.

Table 2. General Chemical Composition and Monosaccharide Content in $L$. rotundiflorus Without Foliage and After Each of the Stages of $\mathrm{HCl}$ Hydrolysis (\%)

\begin{tabular}{|c|c|c|c|c|c|c|c|c|}
\hline & Holocellulose & Lignin & Extractives & $\mathrm{Ara}^{1}$ & $\mathrm{Gal}^{1}$ & $\mathrm{Glu}^{1}$ & $\mathrm{Xyl}^{1}$ & $\mathrm{Man}^{1}$ \\
\hline $\begin{array}{c}\text { Whole plants } \\
\text { without } \\
\text { folliage }\end{array}$ & 62.6 & 15.8 & 22.6 & 3.3 & 11.0 & 61.0 & 24.0 & 0.7 \\
\hline $\begin{array}{c}\text { First step } \\
\text { hydrolysis } \\
(32 \% \mathrm{HCl})\end{array}$ & $\begin{array}{c}31.4 \\
\text { (s.f.) }\end{array}$ & $\begin{array}{c}14.8 \\
\text { (s.f.) }\end{array}$ & nd & $\begin{array}{c}14.8 \\
\text { (l.f.) }\end{array}$ & $\begin{array}{c}12.7 \\
\text { (I.f.) }\end{array}$ & $\begin{array}{c}22.5 \\
\text { (l.f.) }\end{array}$ & $\begin{array}{c}46.5 \\
\text { (l.f.) }\end{array}$ & $\mathrm{tr}$ \\
\hline $\begin{array}{c}\text { Second step } \\
\text { hydrolysis } \\
(42.6 \% \mathrm{HCl})\end{array}$ & $\begin{array}{c}8.0 \\
\text { (s.f.) }\end{array}$ & $\begin{array}{c}14.5 \\
\text { (s.f.) }\end{array}$ & nd & nd & nd & $\begin{array}{c}97.7 \\
\text { (l.f.) }\end{array}$ & $\begin{array}{c}2.3 \\
\text { (l.f.) }\end{array}$ & nd \\
\hline
\end{tabular}

Ara=Arabinose; Gal=Galactose; Glu=Glucose; Xyl=Xylose; Man= Mannose

s.f. = solid fraction; l.f. = liquid fraction

${ }^{1}$ Relative percent composition.

nd, not detected

tr, trace

\section{Acid Hydrolysis}

After the two-step hydrolysis only $8.0 \%$ of the original carbohydrates $(62.6 \%$ holocellulose) remained (Table 2). The difference of 54.6 percent units (48.4 considering the hydrolysis factor) with respect to the original carbohydrates (Table 3) was conceived as hydrolyzed carbohydrates; 31.2 percent units (27.5) and 23.3 percent units (21.0) of the total available sugars were recovered in the first and second phase, respectively. These data are consistent with those obtained when the purified hydrolyzates (thick syrup) were weighed, assuming they are comprised only of hydrolyzed carbohydrates.

The insoluble residue (22.5\%) contained 14.5\% lignin and 8\% undigested carbohydrates. 
Table 3. Hydrolyzed Sugars Yield After the Different Saccharification Steps of $L$. rotundiflorus with $\mathrm{HCl}$, Insoluble Residue and Lost (unrecovered) Material (\%)

\begin{tabular}{|c|c|c|c|c|c|c|}
\hline $\begin{array}{c}\text { Sugars yield } \\
\text { first } \\
\text { hydrolysis }\end{array}$ & $\begin{array}{c}\text { Sugars yield } \\
\text { second } \\
\text { hydrolysis }\end{array}$ & $\begin{array}{c}\text { Sugars } \\
\text { overall } \\
\text { yield }\end{array}$ & $\begin{array}{c}\text { Insoluble } \\
\text { residue }\end{array}$ & Extractives & Total & $\begin{array}{c}\text { Lost } \\
\text { material }^{1}\end{array}$ \\
\hline 27.5 & 21.0 & 48.4 & 22.5 & 22.6 & 87.7 & 12.3 \\
\hline
\end{tabular}

Data are the average of two replicates

Insoluble residue $=14.5 \%$ lignin $+8.0 \%$ undigested carbohydrates

${ }^{1}$ Lost material $=100-\%$ Total

Although the yield from $L$. rotundiflorus was lower than those that can be achieved from biomass sources such as starch (100\%), it represents an important source of fermentable carbohydrates. The conversion of lupine biomass into fermentable sugars would not compete with materials such as starch that are destined for human or animal consumption.

Figure 3 depicts the changes in lignin and holocellulose content with respect to the total original weight of the plant material after each acid hydrolysis stage. As expected, there was a negligible change in the lignin content. Lignin is known to be refractory to acid hydrolysis. However, contrary to lignin, the holocellulose content decreased in proportion to the amount of fermentable sugars obtained in each acid hydrolysis step. Almost all of the hemicelluloses and of the extractives were solubilized by the acidic conditions used in the first stage.

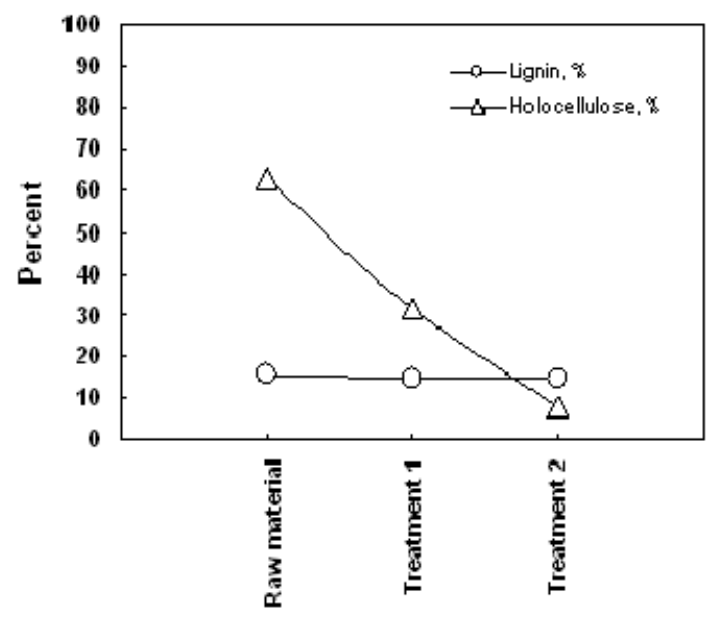

Fig. 3. Holocellulose (sugars) and lignin content variation in raw material (before hydrolysis) and in the insoluble residues after the two stage hydrolysis of $L$. rotundiflorus without leaves

Also shown in Table 2 are the initial content and the monosaccharides released during the first and second hydrolysis stages. The main carbohydrate present in the hydrolyzate after the first stage was xylose (46.5\% relative composition), followed by glucose, arabinose, and galactose, while in the second phase glucose (97.7\%) and xylose (2.3\%) were the only two carbohydrates present. 
The total hydrolysis process used in this study produced, per $100 \mathrm{~g}$ of dry matter, $26.8 \mathrm{~g}$ of glucose (70\% glucan conversion efficiency), $13.2 \mathrm{~g}$ of xylose $(88.1 \%$ conversion), and $7.6 \mathrm{~g}$ of other sugars such as arabinose and galactose (81\% conversion). This is probably due to the fact that pentoses such as xylose and arabinose are easier to hydrolyze from polysaccharides in acidic media than are the hexoses glucose, galactose, and mannose (Moxley and Zhang 2007).

The results from this study are similar to those reported for Lupinus nootkatensis (Kamm et al. 2006). Using the same process they reported 55\% yield in total fermentable carbohydrates, $30 \%$ in the first phase, and 25\% in the second phase. Xylose was 60 to $80 \%$ of carbohydrates present in the first phase with only small quantities of arabinose, glucose, galactose, while in the second phase glucose was $80 \%$ of the carbohydrates, and only traces of xylose, mannose, and galactose were found.

Fermentation processes can be utilized to transform glucose and xylose into alcohols, i.e. ethanol and n-butanol, as well as other chemicals such as furfural. These compounds are or might be the basis for many industrial organic chemicals and substitutes of petrochemical products, including polymers, pharmaceutical, pesticides, dyes, etc.

\section{CONCLUSIONS}

Before and during the flowering stage Lupinus rotundiflorus fibers in the xylem as well as in the external and internal cortex contain little lignin. This facilitates the release of fermentable sugars by acid hydrolysis. Hydrolysis of plant materials released mainly xylose and glucose in the first step and mostly glucose in the second step. It is well known that xylose-based hemicelluloses are more prone to acid hydrolysis in comparison to glucose-based cellulose.

One advantage of this method is the use of a single hydrolyzing reagent in both stages to release fermentable sugars from the plant material. This is combined with the fact that $L$. rotundiflorus is a wild plant that may be easily grown even in poor soils and different climates. The acceptable yield and relative simplicity of this saccharification process, the use of most of the biomass, including roots, but excluding foliage, along with the wide availability, low cost of the chemicals, more efficient acid recovery and the ample supply of lupines, particularly after the development of commercial growing of $L$. rotundiflorus, would facilitate the scaling of these laboratory studies to pilot and industrial levels.

However, hydrochloric acid is a corrosive and dangerous chemical that requires special handling and recycling procedures. The use of enzymes is a well known alternative to acid hydrolysis in obtaining fermentable sugars; however their use may carry along some disadvantages as well, such as relative complexity of the process, as well as concerns about the availability and cost of suitable enzymes. 


\section{ACKNOWLEDGMENTS}

We wish to express our thanks for the financial support received from the Science and Technology National Council (CONACYT) of Mexico, and from the BEMARENA Graduate Studies Program (Biosystems, Ecology, Natural Resources and Agricultural Management) of the Department of Botany/CUCBA, University of Guadalajara, Guadalajara, Mexico.

\section{REFERENCES CITED}

American Society for Testing and Materials (ASTM) (2001). Annual Book of ASTM, E 1758-01, Philadelphia, PA.

Bañuelos, J., and Jiménez, S. (2006). "La importancia y el estado actual del género Lupinus,” in: Lupinos del Occidente de México (Estudios biólogico, bioquímico y toxicológico), Bañuelos, J., Ruiz, M. A., Soltero, R., and Castañeda, H. (eds.), Universidad de Guadalajara, Ediciones de la Noche, Guadalajara México, 13-33.

Bergius, F. (1937) "The production of food-stuffs, alcohol and glucose from wood by means of the Bergius-Rheinau process," Current Science 632-637.

Brennan, A. H., Hoagland, W., and Schell, D. J. (1986). "High temperature acid hydrolysis of biomass using an engineering-scale plug flow reactor: Result of low solids testing,” Biotechnol. Bioeng. Symp. 17, 53-70.

Briceño, B., Azóca, A. R., Fariñas, M., and Rada, F. (2000). “Características anatómicas de dos species de Lupinus l. de los Andes Venezolanos,” Pittieria 1(29 and 30), 2133.

Burger, L. M., and Richter, H. G. (1991). Anatomia da Madeira, Nobel Press, Brasil, 97105.

Converse, A. O., Kwartneg, I. K., Grethlein, H. E., and Ooshima, H. (1989). "Kinetics of thermochemical pretreatment of lignocellulosic materials,” Appl. Biochem. Biotechnol. 20/21, 63-78.

Esteghlalian, A., Hashimoto, A. G., Fenske, J. J., and Penner, M. H. (1997). “Modeling and optimization of the dilute-sulfuric-acid pretreatment of corn stover, poplar and switchgrass,” Bioresour. Technol. 59, 129-136.

Eyal, A. and Baniel, A. (2010). "Process for the recovery of $\mathrm{HCl}$ from a dilute solution thereof,” US Pat. App. 20100093995.

Franklin, G. (1937). "Permanent preparations of macerated wood fibres,” Tropical Woods 49, 21-22.

Fengel, D., and Wegener G. (1984). "Utilization of wood and wood components for chemicals and energy,” in: Wood. Chemistry, Ultrastructure, Reactions, Walter de Gruyter, Berlin, 526-566

Fengel, D., and Wegener, G. (1989). “Cellulose,” in: Wood: Chemistry, Ultrastructure, Reactions, Walter de Gruyter, Berlin, 68-106.

Galbe M. and Zacchi G. (2002). "A review of the production of ethanol from softwood," Appl Microbiol Biotechnol. 59, 618-628. 
Gladstones, J. S. (1998). “Distribution, origin, taxonomy, history and importance,” in: Lupins as Crop Plants: Biology, Production and Utilization, J. S. Gladstones, C. Atkins, and J. Hamblin (eds.), CAB International, UK.

Goldstein, I. S., Pereira, H., Pittman, J. L., Strouse, B. A., and Scaringelli, F. P. (1983). "The hydrolysis of cellulose with superconcentrated hydrochloric acid," Biotechnol. Bioeng. 13, 17-25.

Harris, E. E., and Beglinger, E. (1946). “Madison wood sugar process,” Ind. Eng. Chem. 38, 890-895.

HCL CleanTech (2007). www.hclcleantech.com, accessed December 1, 2010.

Iranmahboob, J., Namied, F., and Monemi, S. B. (2002). "Optimizing acid-hydrolysis a critical step for production of ethanol from mixed wood chips," Biomass Bioenergy 22, 401-404.

Israilides, C. J., Grant, G. A., and Han, Y. W. (1978). “Sugar level, fermentability, and acceptability of straw treated with different acids,” Appl. Environ. Microbiol. 36 (1), 43-46.

Jones, R. W., Krull, L. H., Blessin C. W., and Inglett G. E. (1979). “Neutral sugars of hemicellulose fractions of pith from stalks of selected plants," Cereal Chem. 56 (5), 441-442.

Johnson, J. M.-F., Barbour, N. W., and Weyers S. L. (2007). “Chemical composition of crop biomass impacts its decomposition,” Soil Biol. Biochem. 71(1), 155-162.

Kamm, B., Kamm, M., Schmidt, M., Starke, I., and Kleinpeter, E. (2006). "Chemical and biochemical generation of carbohydrates from lignocellulose-feedstock (Lupinus nootkatensis)-quantification of glucose," Chemosphere 62, 97-105.

Kirk-Othmer (1984). Encyclopedia of Chemical Technology, 3rd Edition, Volume IV. Wiley Interscience, New York, 697-720.

Ladisch, M. R. (1979). “Fermentable sugars from cellulosic residues,” Process Biochemistry 21-25.

Lee, S. B., Ryu, D. D. Y., and Mandels, M. (1982). "Effect of physicochemical properties of cellulose on adsorption and rate of hydrolysis," Biotechnology Bioengineering 24, 2137-2153.

Mandels, M., Andreotti, R., and Roche, C. (1976). "Measurement of saccharifying cellulose,” Biotechnology and Bioengineering Symposium 6, 59-67.

McVaugh, R. (1987). “A descriptive account of the vascular plants of Western Mexico," in: Flora novogaliciana. Vol. V. Leguminosae., The University of Michigan Press, Ann Arbor, MI, USA, 580-599.

Miller, G. L. (1959). "Use of dinitrosalicylic acid reagent for determination of reducing sugars,” Biotechnology and Bioengineering Symposium 5, 193-219.

Moxley, G., and Zhang, Y.-H. P. (2007). "More accurate determination of acid-labile carbohydrate in lignocellulose by modified quantitative saccharification,” Energy \& Fuels 21, 3684-3688.

Pessoa, A. J. R., Manchilha, I. M., and Sato, S. (1997). “Acid hydrolysis of hemicellulose from sugarcane bagasse,” Braz. J. Chem. Eng. 14, 104-164.

Ritter, S. K. (2008). “Lignocellulose: A complex biomaterial,” Plant Biochemistry 86(49), 15. 
Ruiz, M. J. J., Ruiz, M. A., and Zamora, J. F. (2000). “The genus Lupinus: Taxonomy and Distribution in Jalisco, Mexico,” in: Proceedings of the $9^{\text {th }}$ International Lupin Conference, Van Santen, E., Wink, M., Weissmann, S., and Roemer, P. (eds.), Klink/Muritz, Germany, 297-300.

Rzedowski, G. C., and Rzedowski, J. (2001). “Conocimiento y uso de la biodiversidad,” in: Flora Fanerogámica del Valle de México, 2a. ed., Instituto de Ecología, A. C. y Comisión Nacional para el Conocimiento y Uso de la Biodiversidad, Pátzcuaro, Michoacán, México, 298.

Sassner, P., Martensson, C.-G., Galbe, M., and Zacchi, G. (2008). “Steam pretreatment of $\mathrm{H}_{2} \mathrm{SO}_{4}$-impregnated salix for the production of bioethanol," Bioresource Technology 99, 137-145.

Sánchez, O. J., and Cardona, C. A. (2005). “Producción biotecnológica de alcohol carburante I: Obtención a partir de diferentes materias primas,” Interciencia 30(11), 671-678.

Silverstein, R. A., Chen, Y., Sharma-Shivappa, R. R., Boyette, M. D., and Osborne, J. (2007). "A comparison of chemical pretreatment methods for improving saccharification of cotton stalks,” Bioresource Technol. 98, 3000-3011.

Taherzazeh, M. J. and Karimi, K. (2007). “Acid-based hydrolysis processes for ethanol from lignocellulosic materials: A review, "BioResources (http://www.bioresources.com) 2(3), 472-499.

Technical Association of the Pulp and Paper Industry (TAPPI) (2002). TAPPI Standards, Atlanta, Georgia, GA.

Wise, L. E., Murphy, M., and D’Adieco, A. (1946). “Chlorite holocellulose, its fractionation and beating on summative wood analysis and on studies on the hemicelluloses,” Paper Trade J. 122(2), 35.

Article submitted: October 17, 2010; Peer review completed: November 20, 2010;

Revised version received and accepted: December 8, 2010; Published: December 10, 2010. 